\title{
THE COURSE IN LAND TITLES AT THE UNIVERSITY OF ALBERTA*
}

\author{
A. R. THOMPSON
}

\section{PERSPECTIVE OF THE COURSE}

The course in Land Titles at the University of Alberta law school is a two-hour, one-semester course given to third year students. Such a course is an oddity in the curricula of Canadian and United States law schools. Background information will set the perspective in which such an oddity is a compulsory requirement of the third year program.

First, most of the graduates of the Alberta law school find careers in the practice of law within the province. In consequence, the emphasis in the curriculum is on professional courses which are related to the problems of such practice. Second, a unique feature of the sister provinces of Alberta and Saskatchewan, and of the neighboring Northwest Territories, is that the Torrens system of land titles is of universal application. A course on Land Titles is, therefore, a practical necessity in a professionally-oriented law school. Indeed, this necessity has an almost official status, for the Benchers of the Law Society of Alberta recently announced the principle that:

... graduates of a law school other than that of the University of Alberta who have not undergone courses of instruction similar to those provided by that

University in Constitutional Law, Criminal Code of Canada and the Torrens System be required to write examinations in these subjects and undergo any such other courses of instruction as may be determined by the Board of Examiners before being admitted to membership of the Society. (Italics supplied)

Upon graduation a law student in Alberta must enter into articles of clerkship with a member of the bar for a period of one year. Such is the practical importance of land titles that the student often spends a disproportionate part of this year engaged in land titles office practice. The student will become familiar with day-to-day conveyancing, and with the requirements that the Torrens system imposes on the mechanics of title investigation and registration. Because it can be anticipated that the law student will, under professional supervision, become competent in these skills during the period of clerkship, the law school course in Land Titles need not be as technically oriented as this brief perspective might indicate.

\section{OBJECTIVES OF THE COURSE}

\section{Teaching the Law}

In a university law school which is charged with certifying the professional education of candidates for the bar, the law teacher may find himself in an anomalous role. On one hand, his primary objective is to train the student to be a professional man; on the other, his predilection may be to cultivate in the student those qualities which mark a learned man. There is no such anomaly when, in the tradition

-This paper was presented to a tegal education seminar at Columbia University Law School. †Andrew Royden Thompson, LL.B. (Man.), LL.M. (Tor.), Professor of Law at Unlversity

of Alberta Law School. and 20th, 1962. This princlple has not been enacted into a rule in such specifte form. and 20th, 1962. Th1s princlple has not been enacted into a rule in such specile form. in substantive law to be required of those candidates from law schools outside Alberta who seek admission in Alberta without servina a perlod under articles. 
of the bar, it is recognized that the very qualities which justify professional privileges are those which transcend mere technical competence. There is, therefore, the need to teach professional competence in the order of highest intellectual understanding of the subject-matter. This demand requires that the course in Land Titles present the problems of evidencing land ownership in their widest historical, sociological, comparative and doctrinal contexts.

But just as an appreciation of these contexts is necessary to a full understanding of the problems, so is knowledge of the practical context. Therefore, the course in Land Titles must include sufficient information about the day-to-day operations of the land titles system to enable the student to grasp the factual settings in which problems arise. The practical side, then, enters only to the extent necessary to provide adequate background for the conceptual study. It is not that the practical side is unimportant, but that the law school is not an efficient medium for its teaching. Acquiring the practical skills may properly be left to the period of clerkship.

\section{The Educational Process}

The educational psychologist believes the transference of learning to be a phenomenon of limited occurrence. The study of Latin is not, after all, an appreciable benefit for the learning of Chemistry despite the assumptions of our forefathers; and the admonition, "It will be good for you", proves to be a rationalization of grammar school tradition. The degree of transference depends on the closeness of analogy between the study areas. This conclusion may be discouraging for the student of commerce, whose courses of study can be as dissimilar as language and accounting, but it is not so disheartening for the law student, who finds that his fields of study involve essentially similar mental skills. At even the extreme poles of taxation and labour law, the similarity of thought processes probably exceeds dissimilarity. In consequence, it is proper to evaluate even a practical course like Land Titles as contributing to the general educational process. In fact, for the cultivation of powers of analysis and of conceptual thinking, the course in Land Titles has all the advantages of a real property course without the aura of antiquity which usually enfolds, the land law.

\section{The Legislative Process}

Land titles law is in most part statutory law. Given a place in the law school curriculum, its study enables a correction of the imbalance that is evidenced in many law school programs by a disproportionate emphasis on the common law. There is the opportunity to introduce problems of statutory interpretation and reform in a non-controversial setting of "lawyer's law", where the issues are both practical and clear-cut. For example, the extent to which a dower or homestead interest will be permitted to detract from the indefeasibility of title of a purchaser presents problems in statutory interpretation and reform which are pedagogically suitable because the social questions are familar and the issues are clearly defined. The student may see the interaction of policy formulation and implementation in the successive statutory enactments and judical interpretations constituting the history of dower legislation in Alberta. 
The writer has prepared Cases and Notes on Land Titles. It is proposed to show how the objectives set forth for the course are pursued through these cases and notes.

\section{HOW OBJECTIVES ARE ACCOMPLISHED}

\section{Teaching the Law}

The typical conception of land titles registration as a purely mechanical process of recording ownership of land is dispelled by reminding the student that the substantive land law itself evolved in the interstices of procedure. An historical review of the practices of title investigation impresses the student once again with the necessity of finding in remedies the basic principles of property law. In Alberta the Limitations of Actions Act ${ }^{2}$ preserves the distinction by which the running of the limitation period with respect to actions for the recovery of land extinguishes title rather than merely providing a defence to the action. An understanding of constructive fraud can be gained only in historical perspective, and such understanding is crucial to the part which actual or constructive notice plays in the operation of a title system. Throughout the course the student is brought face to face with Judge Cardozo's insight that real property law yields more of its precepts to the historical method than to the methods of logic, tradition or sociology.:

The sociological implications of the Torrens system of land titles are shown by a comparative study of other systems of land registration. The case for the Torrens system was eloquently maintained by its early proponents in Canada, and the student finds impressive the following words of J. Herbert Mason, delivered at a meeting of the Canadian Land Law Amendment Association in 1883:

It will be a grave mistake, if not a lasting disgrace, if, now that an unquestionably better method is known, an antiquated and condemned system, with all its uncertainties, and cumbrous and costly machinery, be inflicted upon the virgin soil of the hope of our Dominion, the Great Northwest. Whoever shall emancipate land from this relic of feudalism; give legislative effect to the Torrens system of transfer by registration; simplify and make uniformly operative the law of descent; abolish general liens and all charges created by operation of law, without registration; and make land as safely and easily dealt with as registered stock or bonds, - will not only be entitled to the thanks of the present generation of his countrymen, but merit the gratitude of millions yet unborn-.

A telling measure of the social utility of the Torrens system is a comparison of the ease and costs of title investigation in Torrens jurisdictions and in "old system" jurisdictions. This comparison, which results so favorably for the Torrens system, can lead to a spirited defence of Torrens against those who decry the injustices that the system's preference of the top title may entail. The consideration of these practical, but doctrinally superficial matters of ease and cost of title investigation, raises questions that are doctrinally fundamental concerning land ownership. The student begins to understand that certainty of dealing with title is in large measure correlative to simplicity of the ownership concept. As the ownership concept becomes more complex, certainty of dealing with title becomes less assured. On the other hand, certainty of dealing with title could be assured with machine-like precision if the concept of ownership of land were limited to absolute

2 R.S.A. 1955, c. 177.

3 The Nature of the Judicial Process, (1921), at 54. 55. 
ownership by a single person of one unqualified estate. The student becomes aware that the Torrens ideal of a system of registration of title so simple that the layman can operate it without professional assistance is feasible only at the cost of inflexibility in the concept of ownership. If he can be led to regard this concept, not only in terms of the tiresome common law estates, but as a vital mechanism in the economic system, he will approach the study of land titles legislation with an eye to discovering those statutory provisions which sacrifice the economic viability of land to the interests of certainty of dealing. To evaluate this sacrifice, he will want to compare these provisions with their counterparts in other registration systems, and his study will be enriched by the catalyst of a critical regard.

The case method of studying law claims its chief merit in presenting legal principles in actual fact situations, and therefore cases are employed to provide the practical context. Fact appreciation is enhanced by introducing the student to the terminology and machinery of the land titles system in two ways. First, the student is required to attend at the land titles office and search a title. Second, the land titles registrar and the chief surveyor willingly come as guest lecturers to explain the functions of their offices. Experience has led these officials to expect the students to ask penetrating questions brought to mind by the study of cases and text materials. Usually, some of the students have been employed during summer months as searchers for law firms or title companies. These students have gained a sufficient familiarity with the land titles system to be capable of probing its more obvious weaknesses.

The cases and notes are not presented as annotations of the land titles legislation. Rather, their study will yield a coherent and structured presentation of the essential principles of the land titles system. Some particular topics are examined in depth. In an oil-conscious province, mineral title problems receive an intensive treatment in line with a general bias in the law school to pay special concern to the legal problems of the petroleum industry.

\section{The Educational Process}

The Torrens system has reaped both flowing rhetoric and capsuled rubric during its history. Rhetoric has embellished its purposes and objects, while rubric, such as "the register is everything", has sought to distill its essence. As often as not, concepts have been distorted as much as they have been clarified by these generalities. Linguistic analysis serves to penetrate the rhetoric and give perspective to the rubric. The student who is brought to realize that the name "Torrens system" works no magic, and that carefully conceived legislation alone can provide a workable system of title registration, will not be mentally numbed by the rhetoric and rubric, but will bring his analytical powers to bear on the legislative problems. He will begin to see that the conceptual differences between Torrens systems and other registration systems are differences of degree more than of substance. All systems of land registration will have to deal with land descriptions, innocent purchasers for value, fraud, notice, encumbrances and a host of other concepts, and the only unique aspect of the Torrens system is that it deals with these concepts with special emphasis on facility and certainty of dealing 
at the expense of flexibility and sanctity of ownership. The problem of notice affecting the title of a purchaser for value, examined first under a Torrens statute and then under an "old system" statute such as the Ontario Registry Act, reveals that the abolition of the actual and constructive notice doctrines by the Torrens statute ${ }^{s}$ achieves results not dissimilar to those attained by the elimination of only the constructive notice rule by the "old system" statute. The reason for the similarity in results under statutes so apparently different in intention is to be found in the larger notion of fraud, of which the doctrines of actual and constructive notice are part. Notwithstanding the abolition of the doctrine of actual notice, the court trying a case under the Torrens statute will not acquit a purchaser for value who has acquired title with actual notice of a prior competing claim if the circumstances of acquiring title were tainted with "actual fraud" or "moral turpitude", for fraud is always an exception to indefeasibility of title. In practical result, it is the rare case in which the presence of actual notice will not result in a finding of "actual fraud", vitiating the Torrens title." At this point, the bright student will see that this similarity of results under the two systems is implicit in the nature of notice and fraud. If actual notice of a competing prior claim is not "actual fraud" when acquiring title, then he will insist on knowing what additional ingredient in the conduct of the purchaser is required to earn the opprobrium "actual fraud". He will not be satisfied by an unspecified "something more". If this requirement is specified to be a dishonest intention in addition to actual notice, he will press the inquiry into the circumstances which can amount to dishonesty. If the vice of circularity in reasoning is to be avoided, these circumstances cannot be knowledge of the prior claim at the time of acquiring title. If they are conceded to be the motive, for good or for evil, with which the title is acquired by the purchaser, the case seems to violate the common law principle that ordinarily the motive of the actor is irrelevant if his conduct is otherwise lawful. It also seems to involve the absurdity that the purchaser is protected if he understands the law to say that he can procure good title notwithstanding his knowledge of a prior competing claim, but not protected if he believes that the law does not say this and that doing so is illegal and dishonest. ${ }^{7}$ If these circumstances which earn the opprobrium "actual fraud" are said to be those that moral standards declaim as dishonest, the perceptive student will be sceptical that there are moral standards in this situation that are not merely derivative of the rules of property law. If this scepticism is justified, the honesty or dishonesty of the purchaser's conduct by moral standards depends on a test of whether or not a good legal title can be acquired notwithstanding knowledge of a prior competing claim. This path returns to actual notice, and poses the conundrum that, while fraud depends on dishonesty, and dishonesty depends on actual notice vitiating title for fraud, the statute says that actual notice is not by itself to be imputed as fraud. This analysis of the problem leads to the con-

I R.S.O. 1950, c. 336.

s Land Tittes Act, R.S.A. 1955, c. 170, 8. 203. This statutory provision gays that actual or constructive notice shall not of itself be imputed as traud, any rule of law or equity to the contrary nothwithstanding.

- One such case is Hackworth v. Baker, [1936] 1 W.W.R. 321.

T The opinton of counsel was an Important conslderation In Ross v. Stovall, [1919] 1 W.W.R. 673, 14 Alta. L.R. 334. 45 D.L.R. 397. 
clusion that there may be a logical impasse in the statutory attempt to abolish the doctrine of actual notice and at the same time preserve the vitiating effect of fraud. It leads one to expect that circumstances amounting to actual notice, whether in an "old system" or a Torrens system jurisdiction, will ordinarily vitiate the title of a purchaser. The exceptions will be those few cases where unusual circumstances invest the transaction with such an aura of innocence that the court can, in conscience, and without concern for logical niceties, apply the Torrens provision that actual notice shall not of itself be imputed as fraud.

The subject of land registration is replete with conceptual problems. Professor H. L. A. Hart of Oxford has stated his conviction that studies in analytical jurisprudence are the best exercises for developing in the law student those conceptual and analytical powers which are the fibre of the critical mind.' The course in Land Titles is admirably suited to strengthen those conceptual and analytical powers. It will be the witless student who uses loosely such terms as "equity", "fraud" or "notice".

\section{The Statutory Process}

In 1954 it was held that an error made in the land titles office deprived the Canadian Pacific Railway of title to petroleum in a. quarter section of land. This decision, which was later affirmed in the Supreme Court of Canada," attracted world-wide notoriety to the Alberta Torrens system. Theodore Ruoff, the English deputy land registrar, entitled a chapter of his book "Mineral Titles-Backsliding in Alberta".20 The reasons for this notoriety are not difficult to find. The error in question was a mere slip of the pen by a land titles official made as long ago as 1906 , but it cost the Canadian Pacific Railway $\$ 5,000,000$ in petroleum rights. This case is that rare one which excites the imagination of the student as it dramatizes basic issues. At stake was the question whether a bona fide purchaser for value relying on a registered title including petroleum by reason of an error of a land titles official was to receive title to the petroleum indefeasible by the true owner. Also at stake was the extent to which the Assurance Fund was to be an integral part of a policy choice in favour of the purchaser for value, because it was at once apparent that payment of compensation for deprivation of petroleum in the many situations of which this case was the prototype would strain the provincial treasury. Amid the spectre of bankruptcy and the opprobrium of "backsliding", a Special Committee of the Benchers of the Law Society of Alberta was appointed with the authority of the provincial government to investigate and recommend reform of the land titles statute. The committee reported in 1956, ${ }^{11}$ and certain patchwork reforms were immediately enacted. The overall reform of the legislation has been in the hands of legislative draftsmen since that time with a draft bill still awaited.

These events present Land Titles as a vital subject in which statutory reform is not merely an ideal but a necessity. The report of the Special Committee earmarks the key issues in a stark simplicity which enables

\footnotetext{
8 Analytical Jurisprudence-A Reply to Professor Bodenheimer, 105 U. of Penn. L. Rev. 953 (1957).

o Turta v. C.P.R., [1954] S.C.R. 427.

10 An Enolishman Looks at the Torrens System, 1959.

11 Tille to Minorals in Alberta, The Report of the Bonchers' Special Committee, 1956, 1 Alta. L. Rev. 185.
} 
the student to grasp them at the outset of the course. He can then begin to form opinions on these issues as he becomes familiar with the case law and other materials. He is brought to see that the problems of the oil industry with respect to mineral titles are not identical with the problems of the purchaser of a house or a commercial property, and that oil industry solutions may have the aspect of throwing the baby out with the bath-water from the latter's point of view. He will wonder whether the exemption of the Crown from registration requirements is a justifiable privilege or an unjust anachronism. The Land Titles course provides an outstanding opportunity to give the student some insight into the legislative process and to inculcate a sense of responsibility for legislative reform.

\section{The Teacher's Role}

A professor of accounting whose teaching skill was legendary among law students at the University of Alberta maintained that the basic ingredient of good teaching is the instructor's enthusiasm for his subject. Possibly an oversimplification, this credo nevertheless points the necessity of stimulating and challenging course content. The content of a land titles course can provide excitement and challenge, and it remains only for the teacher to quicken these qualities in the student.

The writer, as a teacher of Land Titles, seeks not only to inculcate analytical powers and to impart a sense of the practical and social values of the subject, but also to arouse in his students some of the drama of its judicial and legislative evolution. He has, therefore, selected those cases and materials which most strikingly present the issues and reveal the conflicts. The lecture hour proceeds rather as a discussion period than as either the usual case method dialogue or a formal lecture. The students, as third-year students, are expected to have absorbed the materials sufficiently before class to be able to participate in a discussion ranging over a number of cases and aimed at elucidating the more general issues. Hypothetical problems, often suggested by the local registrar or practitioners, and proposals for legislative reform are employed to focus discussion and to provide realism.

The writer brings to his teaching of the subject practical experience in both "old system" and Torrens system jurisdictions, and his special concern with the problems of mineral titles contributes to his personal commitment that "Land Titles, too, Can be Beautiful".." 